İşletme Akademisi Dergisi
$2020,1(1): 1-16$
DOI: $10.26677 / T R 1010.2020 .348$
Dergi web sayfast: www.isakder.org

Araștırma Makalesi

\title{
Isı Yalıtım Sektöründe Maliyet Muhasebesi Uygulaması ve Bir Alan Çalışması ${ }^{1}$
}

\section{Prof. Dr. Zeynep HATUNOĞLU}

Kahramanmaraş Sütçü İmam Üniversitesi, İktisadi ve İdari Bilimler Fakültesi İşletme Bölümü zhatunoglu@hotmail.com, www.orcid.org/0000-0002-9103-2766

\section{Dr. Öğrencisi Tuba ALAYBEYOĞLU}

Kahramanmaraş Sütçü İmam Üniversitesi Sosyal Bilimler Enstitüsü tuba-alayby-2@hotmail.com, www.orcid.org/0000-0003-3830-8089

\section{Öz}

Enerji kaynaklarının hızlı bir şekilde tüketilmesi, enerjinin tasarruflu bir şekilde kullanılması gerekliliğini ortaya koymuştur. Isı yalıtım uygulamaları ile yapılarda enerji tasarrufunun sağlanabiliyor olması, ısı yalıtım malzemelerinin üretimini önemli kılmaktadır. Bu çalışma, XPS 1sı yalıtım levhalarının üretim süreci ve maliyetleri hakkında bilgi sağlayarak, işletmenin uygulamış olduğu maliyet sisteminin değerlendirilmesi amacıyla yapılmıştır. Çalışmamız Kahramanmaraş ilinde faaliyet gösteren Ekstrüde Polistren Köpük (XPS) 1sı yalıtım levhası üretimi yapan bir işletmede gerçekleştirilmiştir.

XPS ısı yalıtım levhasının üretim süreci ayrıntılı bir şekilde gözlenmeye çalışılmış ayrıca yetkili kişiler ile bu konuda görüşülerek bilgiler alınmıştır. Bununla birlikte muhasebe departmanındaki kişilerle görüşülmüş ve mevcut maliyet sistemi incelenmiştir. Ayrıca işletmede uygulanan maliyet sistemi ve işletme içerisinde gerçekleştirilen uygulamalar incelenerek bazı eksiklikler tespit edilmiş ve bu eksikliklerin giderilmesi için önerilerde bulunulmuştur.

Anahtar Kelimeler: XPS Isı Yalıtım Levhası, Isı Yalıtımı, Muhasebeleştirme.

Makale Gönderme Tarihi: 05.02.2020

Makale Kabul Tarihi: 11.03 .2020

\footnotetext{
${ }^{1}$ Bu çalışma "Isı Yalıtım Sektöründe Maliyet Muhasebesi Uygulaması ve Bir Alan Çalışması" isimli tezden türetilmiştir.

\section{Önerilen Atıf:}

Hatunoğlu, Z. ve Alaybeyoğlu, T., (2020). Isı Yalıtım Sektöründe Maliyet Muhasebesi Uygulaması Ve Bir Alan Çalışması, İşletme Akademisi Dergisi, 1(1): 1-16.

(C) 2020 İşletme Akademisi Dergisi.
} 


\title{
Journal of Business Academy
}

2020, 1 (1): $1-16$

DOI:10.26677/TR1010.2020.

Web pages: www.isakder.org

Research Article

\section{Cost Accounting in Heat Insulation Sector and A Field Study}

\section{Prof. Dr. Zeynep HATUNOĞLU}

Kahramanmaraş Sütçü İmam University, Faculty of Economics and Administrative Sciences zhatunoglu@hotmail.com, www.orcid.org/0000-0002-9103-2766

\section{Ph.D. Candidate Tuba ALAYBEYOĞLU}

Kahramanmaraş Sütçü İmam University, Institüte of Social Sciences

tuba-alayby-2@hotmail.com, www.orcid.org/0000-0003-3830-8089

\begin{abstract}
The rapid consumption of energy resources has shown the necessity to use energy in an efficient way. The fact that energy saving can be achieved in the buildings with heat insulation applications makes the production of heat insulation materials important. This study was conducted to evaluate the cost system of the enterprise by providing information about the production process and costs of XPS heat insulation boards. This study was carried out in a company which produces Extruded Polystyrene Foam (XPS) thermal insulation board in Kahramanmaraş.

The production process of the XPS heat insulation board has been tried to be observed in detail and also information has been obtained with the authorized persons. In addition, people in the accounting department were been interviewed and the current cost system was examined. Also the cost system applied in the enterprise and the practices carried out were examined and some shortcomings were identified and suggestions were made to eliminate these deficiencies.
\end{abstract}

Keywords: XPS Heat Insulation Board, Heat Insulation, Accounting.

Received: 05.02.2020

Accepted: 11.03 .2020

\section{Suggested Citation:}

Hatunoğlu, Z. and Alaybeyoğlu, T., (2020). Cost Accounting in Heat Insulation Sector and A Field Study, Journal of Business Academy, 1(1): 1-16.

(C) 2020 Journal of Business Academy. 


\section{GİRIŞ̧}

Kıt olan enerji kaynaklarının verimsiz bir şekilde kullanılması nedeniyle insanlar bu kaynakların tükenme riski ile karşı karşıya kalmışlardır. Yenilenemeyen enerji kaynaklarının hızlı bir şekilde tüketilmesi, özellikle enerji bakımından dışa bağımlı olan ülkeler için bazı önemli tedbirlerin alınmasını gündeme getirmiştir. Ülkemiz enerji kaynakları bakımından kendi ihtiyacını karşılayamamakta ve tükettiği enerjinin önemli bir kısmını ithal etmektedir (İşbilir, 2009: 11). Türkiye'de konutlarda tüketilen enerjinin \%80'i 1sitma ve soğutma amaçlarıyla kullanılmaktadır (Kaya, 2016:1). Enerji tüketiminin alt seviyelere çekilmesi oldukça önemlidir. Bunun için yapılarda 1sı yalıtım uygulamaları yürürlüğe giren yönetmeliklerle zorunlu tutulmaya çalışılmaktadır. Ülkemizde 1 sı yalıtımı konusunda yapılan ilk düzenleme 1968 yılında İmar ve İskan Bakanlığı tarafından "Yapıda Isı Tesirinden Korunma" isimli "Halk Konutları Standardı" dır. Sonrasında 1970 yılında Türk Standartları Enstitüsü tarafından TS 825 "Binalarda Isı Yalıtım Kuraları" yayınlanmıştır (Karayiğit, 2015: 20). 03.10.1977 Tarihli 16102 sayılı Resmi Gazete'de "Isıtma ve Buhar Tesislerinin Yakıt Tüketiminde Ekonomi Sağlanması ve Hava Kirliliğinin Azaltılması Yönetmeliğgi". 19.11.1984 Tarihli ve 18580 sayılı Resmi Gazete'de "Mevcut Binalarda 1sı Yalıtımı ile Yakıt Tasarrufu Sağlanması ve Hava Kirliliğinin Azaltılmasına Dair Yönetmelik" ve 08.05.2000 Tarihli ve 24043 sayılı Resmi Gazete'de "Binalarda Isı Yalıtımı Yönetmeliği" yayınlanarak yürürlüğe girmiştir. 14.06.1999 tarihli Resmi Gazete'de TS 825 "Binalarda Isı Yalıtım Kuraları" revize edilerek yayımlanmıştır. Bu standarda göre 14.06.2000 tarihinden itibaren ülkemizde inşa edilen tüm ruhsatlı binalarda bu standarda uyulacaktır (www.mmo.org.tr). 09.10.2008 Tarihli ve 27019 sayılı Resmi Gazete'de "Binalarda Isı Yalıtımı Yönetmeliği" ve 05.12.2008 Tarihli ve 27075 sayılı Resmi Gazete'de "Binalarda Enerji Performansı Yönetmeliği" yayımlanmıştır. Bu yönetmelikler ile hem enerji tasarrufu sağlanması, hem ısı kaybının önlenmesi hem de çevre kirliliğinin azaltılması amaçlanmaktadır.

Günümüzde işletmelerin ana gider kalemlerinden biri haline gelen enerjinin tasarrufu konusunda yeni politikalar geliştirilmekte ve enerji tasarrufu yapılması yasal düzenlemelerle teşvik edilmektedir (www.muhasebetr.com). Bu yasal düzenlemeler; 15.07.2016 tarihli ve 29796 sayılı Resmi Gazete'de yayımlanan “6728 sayılı Yatırım Ortamının İyileştirilmesi Amacıyla Bazı Kanunlarda Değişiklik Yapılmasına Dair Kanun" ile 20.08.2016 tarih ve "6745 sayılı Yatırımların Proje Bazında Desteklenmesi İle Bazı Kanun Ve Kanun Hükmünde Kararnamelerde Değişiklik Yapılmasına Dair Kanun"'dur (www.guncelgroup.com.t). 6728 sayılı Yatırım Ortamının İyileştirilmesi Amacıyla Bazı Kanunlarda Değişiklik Yapılmasına Dair Kanun'un 14. Maddesi ile 193 sayılı Gelir Vergisi Kanunu'nun 40. Maddesinin birinci fıkrasının 7 numaralı bendine "İşletmeye dâhil olan gayrimenkulün iktisadi değerini artırıcı niteliği olan ısı yalıtımı ve enerji tasarrufu sağlamaya yönelik harcamalar, yapıldığı yılda doğrudan gider yazılabilir" ibaresi eklenmiştir. Yapılan bu düzenleme ile daha önce gayrimenkulün maliyetine eklenerek yıllar itibarıyla amortisman adı altında itfa edilen harcamanın bir defada gider yazılabilmesine olanak sağlanmıştır. 6745 sayılı Yatırımların Proje Bazında Desteklenmesi İle Bazı Kanun Ve Kanun Hükmünde Kararnamelerde Değişiklik Yapılmasına Dair Kanun'un 6. Maddesi ile 193 sayılı Gelir Vergisi Kanunu'nun 74 üncü maddesinin birinci fıkrasının (6) numaralı bendine "...ile kiraya veren tarafından yapılan ve gayrimenkulün iktisadi değerini artırıcı niteliği olan ısı yalıtımı ve enerji tasarrufu sağlamaya yönelik harcamalar (Bu harcamalar bir takvim yılı içinde Vergi Usul Kanununun 313 üncü maddesinde belirlenen tutarı aşıyor ise maliyet olarak dikkate alınabilir)" ibaresi ilave edilmiştir. Yapılan bu düzenlemelerle işletmelere 1sı yalıtımı ve enerji tasarrufu sağlamaya yönelik yapılan sözleşme ve işlemlerde damga vergisi ve harçlardan muaf tutulma imkanı verilmiştir (Erkan, 2017: 186). Enerji tüketimi sırasıyla sanayi alanında, ulaşım alanında ve yapılarda gerçekleşmektedir. Enerji kaynakları 
yapılarda 1sıtma ve soğutma amacıyla kullanılmaktadır. Isı yalıtım uygulamaları ile yapılarda kullanılan enerji miktarı azalmaktadır.

Yalıtım yapılarda 1sı yalıtımı, ses yalıtımı ve su yalıtımı şeklinde yapılabilmektedir. Isı yalıtımı, yapılarda ısı kayıp ve kazançlarının engellenmesi amacıyla yapılmaktadır. Ses yalıtımı, seslerin engellenmesi amacıyla yapılmaktadır. Su yalıtımı, yapıların suya karşı korunması amacıyla yapılmaktadır. Isı yalıtımı farklı sıcaklıktaki iki ortam arasında 1sı transferini azaltmak için yapılan işlem olarak tanımlanabilir (Alyanak Kaya, 2010: 19). Isı yalıtımı yapıların döşemelerinde, duvarlarında ve çatılarında gerçekleştirilebilmektedir. Uygulamanın yapılacağı yerin özelliklerine göre farklı 1Sı yalıtım malzemeleri kullanılmaktadır. Isı yalıtım malzemelerinin seçiminde uygulamanın yapılacağı yerin ve alanın özellikleri dikkate alınmaktadır. Örneğin, yüksek sıcaklığa sahip ortamlarda kullanılacak olan 1sı yalıtım malzemelerinin yanmaya karşı dirençli bir yapıya sahip olması gerekir.

Yapılarda, ısı farkından kaynaklanan ısı kayıp ve kazançlarının azaltılması amacıyla kullanılan malzemelere "1sı yalıtım malzemeleri" denir. Bu malzemeler yüksek ısıl dirence sahiptirler. Malzemelerin yalıtım özelliklerini arttıran ısı iletkenlik kat sayıları, yalıtımın kalitesi açısından büyük öneme sahiptir (www.baypratik.com).

Isı yalıtımında farklı malzemeler kullanılabilmektedir, bu malzemelerinden biri olan Ekstrüde polistren köpük (XPS) köpük şeklinde üretilen bir malzemedir. XPS, üretiminde kullanılan hammadde polistren denilen tanecikli bir malzemedir (www.yalitimrehberi.net). XPS, duvarların, çatıların veya döşemelerin yalıtımında kullanılabilir. Suya karşı dayanıklıdır. Aynı zamanda çürümez veya parçalanmaz bir malzemedir. Ağırlı̆̆ının fazla olmaması nedeniyle taşınması ve uygulanması kolay bir yalıtım malzemesidir. Isı iletkenliği düşük olan bu ısı yalıtım malzemesi, diğer malzemelere göre daha iyi bir yalıtım imkânı sunmaktadır (www.docplayer.biz.tr).

Isı yalıtımı ile ilgili akademik çalışmalar daha çok Fen Bilimleri alanında yapılmıştır. Karadayı ve Yüksek (2016) yaptıkları makale çalışmasında piyasada satılan ısı yalıtım malzemeleri ve 1sı yalıtım özeliği gösteren malzemelerin analizini yaparak 1sı yalıtım malzemelerinin sahip olması gereken özellikleri anlatmışlardır. Bektaş, Çerçevik ve Yerel Kandemir (2017) yaptıkları makale çalışmasında binalarda ısı yalıtımının öneminden bahsederek yalıtım kalınlığının ısı yalıtım üzerindeki etkisini değerlendirmişlerdir. Karayiğit (2015) yaptığı yüksek lisans tezinde konutlara uygulanan farklı 1sı yalıtım malzemeleri, bunların özellikleri ve yalıtımın yıllık yakıt tüketimine etkisini ortaya koymuştur. Yapılan analizler sonucunda isı yalıtımıyla yıllık ısıtma enerjisi kullanımında \%80 oranında tasarruf edildiği sonucuna ulaşılmıştır. Ögetürk (2019) yaptığ1 yüksek lisans tezinde binalarda $1 S 1$ yalıtım malzemelerinin enerji verimliliği üzerine etkisini araştırmıştır. Yapılan bu çalışmalarda daha çok 1 sı yalıtım malzemelerinin teknik özelikleri anlatılarak ekonomik analizleri yapılmış, 1 sı yalıtım malzemelerinin enerji verimliliği üzerine etkisi incelenmiş ve binalarda 1sı yalıtım uygulamaları ve sorunları tespite çalışılmıştır. Erkan (2017) yaptığı makale çalışmasında işletmelerin $1 s ı$ yalıtımı ve enerji tasarrufuna yönelik yaptıkları masrafları giderleştirme durumunu incelemiştir. Çalışmamızda ise 1 ș yalıtım malzemelerinden biri olan XPS'in üretim süreci, maliyetleri, maliyet hesaplama şekli hakkında bilgi verilmesi amaçlanmaktadır. Bu bağlamda Kahramanmaraş ilinde bulunun bir ısı yalıtım işletmesinde örnek uygulama çalışması yapılmıştır. İlgili işletmede $1 s ı$ yalıtım malzemesinin üretim süreci ve muhasebe uygulamaları hakkında bilgi verilerek önerilerde bulunulmuştur. 


\section{ARAŞTIRMANIN YÖNTEMI}

$\mathrm{Bu}$ çalışmanın amacı, Kahramanmaraş ilinde 1Sı yalıtım sektöründe faaliyette bulunan ve XPS 1S1 yalıtım levhası üreten bir işletmede, XPS 1Sı yalıtım levhasının üretim süreci ve maliyetlerinin hesaplanışı hakkında bilgi vermektir.

$\mathrm{Bu}$ amaçla öncelikle işletmenin üretmiş olduğu ürünler, ürün özellikleri ve üretim süreci hakkında bilgiler verilecektir. Ardından muhasebe departmanında gerçekleştirilen işlemler ve işletme de uygulanan maliyet muhasebe sistemi açılanmaya çalışlacaktır. Sonrasında ise üretim maliyetleri çıkartılarak birim üretim maliyeti hesaplanacaktır. Uygulama, muhasebe birimiyle ilgilenen sorumlularla birebir görüşülerek ve işletmede gözlem yapılarak gerçekleştirilmiştir.

\section{1. Örnek İşletmenin Ürettiği Ürünler ve Teknik Özellikleri}

XPS 1S1 yalıtım malzemelerinin üretiminde kullanılan polistren malzemesinin 1S1 iletim kat sayısı 0.030-0.035-0,040 W/ mK, sicaklığı $-50 /+75 \sim+80^{\circ} \mathrm{C}$ aralığında olup ve yoğunluğu 20-50 $\mathrm{kg} / \mathrm{m}^{3}$ 'dür (www.xpsturkiye.org). Bu malzeme üretim hattında eritilir ve içerisine şişirme ajanı eklenir. Şişirme ajanın eklenmesinin nedeni, malzemenin köpüksü yapısının elde edilebilmesidir. Uygulamanın yapılacağı yerin özelliğine göre, ihtiyaç duyulan kalınlıkta üretimi gerçekleştirilebilmektedir. Havanın hapsedilmesi ile dirençli bir hücre yapısı elde edilir. Malzemenin yüzeyi, hattaki işlemlerinin bitiminden sonra, isteğe bağlı olarak zırhlı veya pürüzlü olacak şekilde işleme tabi tutulmaktadır (www.yalitimrehberi.net). XPS 1sı yalıtım levhaları, uygulamanın yapılacağı yerin özelliklerine göre farklı kalınlık ve yoğunluklarda üretilmektedir. XPS ısı yalıtım levhaları kalınlıkları ve tipleri ile isimlendirilmektedir. İşletmede üretim $\mathrm{m}^{3}$ üzerinden yapılmaktadır. Aşağıdaki tabloda üretim çeşitleri ve özellikleri yer almaktadır.

Tablo 1. XPS Yalıtım Levhasına Ait Teknik Bilgiler

\begin{tabular}{|c|c|c|c|c|}
\hline Kalınlı $\mathbf{( c m )}$ & Ebad $\mathbf{( c m )}$ & $\mathbf{m}^{\mathbf{3}}$ & Tip & Yoğunluk (kg) \\
\hline $2 \mathrm{~cm}$ & $600 \times 1200$ & 0,288 & BYP 2000 & 24-26 Danste \\
\hline $3 \mathrm{~cm}$ & $600 \times 1200$ & 0,3024 & BYP 1500 & 22-24 Danste \\
& & & BYP 2000 & 24-26 Danste \\
& & & BYP 3000 & 28-32 Danste \\
\hline $4 \mathrm{~cm}$ & $600 \times 1200$ & 0,288 & BYP 1500 & 22-24 Danste \\
& & & BYP 2000 & 24-26 Danste \\
& & & BYP 2500 & 26-30 Danste \\
& $600 \times 1200$ & 0,288 & BYP 3000 & 28-32 Danste \\
\hline $5 \mathrm{~cm}$ & & & BYP 2000 & 22-24 Danste \\
& & & BYP 2500 & 26-30 Danste \\
& & & BYP 3000 & 28-32 Danste \\
\hline $6 \mathrm{~cm}$ & $600 \times 1200$ & 0,3024 & BYP 2000 & 24-26 Danste \\
& & & BYP 3000 & 28-32 Danste \\
\hline $7 \mathrm{~cm}$ & $600 \times 1200$ & 0,3024 & BYP 2000 & 24-26 Danste \\
& & & BYP 2500 & 26-30 Danste \\
& & & BYP 3000 & 28-32 Danste \\
\hline
\end{tabular}

Örnek işletmede ebat ve yoğunlukları (danste) açısından 6 çeşit isı yalıtım levhası üretilmektedir. Bunlar;

- Kalınlığı $2 \mathrm{~cm}$ olan $1 s ı$ yalıtım levhası tek tip halinde üretilmektedir. Bu yalıtım levhasının ebadı 600x1200 cm, 0,288 m³ tür. 24-26 danstenin (bir m³'ün kg karşılığı) tipi BYP 2000' dir. 
- Kalınlığı $3 \mathrm{~cm}$ olan $1 s ı$ yalıtım levhası üç tip halinde üretilmektedir. Bunların ebatları ve $\mathrm{m}^{3}$ aynıdır. Ebadı 600x1200 cm ve 0,3024 m³'tür. 22-24 danstenin tipi BYP 1500, 24-26 danstenin tipi BYP 2000 ve 28-32 danstenin tipi BYP 3000'dir.

- Kalınlığ $4 \mathrm{~cm}$ olan $1 s ı$ yalıtım levhası dört tip halinde üretilmektedir. Bunların ebatları ve $\mathrm{m}^{3}$ aynıdır. Ebadı 600x1200 cm ve 0,288 m³'tür. 22-24 danstenin tipi BYP 1500, 24-26 danstenin tipi BYP 2000, 26-30 danstenin tipi BYP 2500 ve 28-32 danstenin tipi BYP 3000'dir.

- Kalınlığ $5 \mathrm{~cm}$ olan ısı yalıtım levhası dört tip halinde üretilmektedir. Bunların ebatları ve $\mathrm{m}^{3}$ aynıdır. Ebadı 600x1200 cm ve 0,288 m³'tür. 22-24 danstenin tipi BYP 1500, 24-26 danstenin tipi BYP 2000, 26-30 danstenin tipi BYP 2500 ve 28-32 danstenin tipi BYP 3000'dir.

- Kalınlığ $6 \mathrm{~cm}$ olan ısı yalıtım levhası iki tip halinde üretilmektedir. Bunların ebatları ve $\mathrm{m}^{3}$ aynidır. Ebadı 600x1200 cm ve 0,3024 m³'tür. 24-26 danstenin tipi BYP 2000 ve 28-32 danstenin tipi BYP 3000'dir.

- Kalınlığı $7 \mathrm{~cm}$ olan ısı yalıtım levhası üç tip halinde üretilmektedir. Bunların ebatları ve $\mathrm{m}^{3}$ aynidır. Ebadı 600x1200 cm ve 0,3024 m³'tür. 24-26 danstenin tipi BYP 2000, 26-30 danstenin tipi BYP 2500 ve 28-32 danstenin tipi BYP 3000'dir.

\section{2. Örnek İşletmenin Kullandığı Malzemeler}

XPS isı yalıtım levhasının üretiminde 7 çeşit malzeme kullanılmaktadır. Üretimde kullanılan direkt ilk madde malzemeler; polistren, talk, renk, alev geciktirici ve dimetileter gaz'dır. Endirekt ilk madde ve malzemeler ise baskılı ambalaj poşeti ve etiket' tir.

1. Polistren: Levha üretiminde kullanılan en önemli hammaddelerden biridir. Polistren, 1S1 vasitasıyla eriyik hale getirilmektedir. Sert bir malzemedir. Yüzeyi parlak ve kırılgan bir yapıya sahiptir. Petrolden üretilen polistren yakıldığında etrafa gaz kokusu yaymaktadır.

2. Talk: XPS 1 sı yalıtım levhalarının üretilmesinde kullanılan diğer hammadde "talk" tır. Talk, malzeme şişerken içerisinde oluşan gözeneklerin doldurulmasını sağlar. Bu hammadde yumuşak bir mineraldir. Neme ve rutubete karşı korunması gerekir.

3. Renk: XPS isı yalıtım levhasına renk verilmesinde kullanılan malzemedir. Kimyasal bir maddedir. İçeriğinde petrol bulunmaktadır. Bundan dolayı üretim yerinde çalışan işçiler maske kullanmaktadır.

4. Alev Geciktirici: XPS ısı yalıtım levhalarının, yanmasının zorlaştııılması amacıyla kullanılan bir malzemedir.

5. Dimetileter Gaz: XPS yalıtım levhasının üretiminde kullanılan bir diğer hammadde ise dimetileter gazıdır. Bu hammadde şişirme gazı olarak kullanılmaktadır. Çevre dostu olan dimetileter gaz, kokusuz ve renksizdir.

6. Baskılı Ambalaj Poșeti: Üretilen XPS 1sı yalıtım levhalarının paket haline getirilmesinde kullanılan endirekt ilk madde ve malzeme ambalaj malzemesidir.

7. Etiket: Ürünün özelliğinin gösterilmesi için kullanılan diğer endirekt ilk madde ve malzemeye "etiket" denir. Etiketin üzerinde levhanın kalınlığı, ısıl direnci, boyutları, kaç adet olduğu, yangına tepki sınıfı, basma mukavemeti, 1sı iletkenliği, üretim tarihi gibi bilgiler yer almaktadır. Ayrıca etiketin üzerinde ürünlerin TS EN13164 ve CE Avrupa Birliği Standartlarına uygun olarak ISO9001:2015 üretim sistemine uygun olarak üretildiği bilgisi de yer almaktadır.

\section{3. Örnek İşletmede XPS Üretim Aşamaları}

İşletmede üretim 10 aşamadan oluşmaktadır. Bunlar; mikser ve dozajlama aşaması, 1. Eksturüler aşaması, 2. Eksturüler aşaması, kalibrasyon ve çekme aşaması, soğutma rulöleri aşaması, pürüzleme aşaması, yan bini aşaması, boy kesme aşaması, son bini aşaması ve paketleme aşamalarıdır. 
1. Mikser ve Dozajlama Așaması: Hammaddelerin karıştıııldığı silolardır. Değişik türden hammaddeler, hücre yapıcı (talk) ve renk tartılı sistemde üretime hazır hale getirilmektedir.

2. 1. Eksturüler așaması: Isı vasıtasıyla hammadde, vida boyunca ilerleyerek eriyik hale gelir. Eriyik hale gelen hammaddeye, bu aşamanın sonunda yüksek basınçlı pompa vasıtasıyla gaz enjekte edilir ve şişme aşaması başlamış olur.

3. 2. Eksturüler așaması: Soğutma bölümü olarak bilinen bu aşamada, malzeme hem soğur hem de şişme evresini vida boyunca devam ettirir. Hattın sonunda olan döküm kafa sayesinde belirlenen kalınlıkta kek formunda malzeme çıkmaya başlar.

4. Kalibrasyon ve Çekme Așaması: Kek formunda çıkan malzeme, son detaylık kalınlık ayarını bu aşamada alır ve soğutma rulölerine çekme silindiri sayesinde aktarılır.

5. Soğutma Rulöleri Așaması: Yaklaşık 15 metre boyunca şişmiş malzeme bu aşamada soğutulur.

6. Pürüzleme Aşaması: $\mathrm{Bu}$ aşamada levhaların, alt ve üst yüzeyindeki zırhlı tabaka pürüzlenerek, uygulamada sıva tutmasına elverişli hale getirilir.

7. Yan Bini Așaması: Bu aşamada, uygulamada yan yana gelen levhaların birbirinin üzerine geçmesi amacıyla iki yan kenarlara lamba zıvana biniler açılır.

8. Boy Kesme Așaması: Levhanın standart uzunluklarda kesme işleminin yapıldığı aşamadır.

9. Son Bini Aşaması: Kalan kısa kenarlar için lamba zıvana binilerinin açılmış olduğu aşamadır. Böylece levhanın yüzeyleri pürüzlenmiş ve kenar binileri açılmış hale gelmiş olur.

10. Paketleme Așaması: Bu aşamada hazırlanan levhalar belirli sayılarda paketlenerek sevkiyata hazır hale getirilir.

\section{4. Örnek İşletmede Yapılan Muhasebe Kayıtları}

İşletmede İlk madde ve malzemeler satın alındığında 150 İlk Madde ve Malzeme Hesabı borçlandırılmaktadır. Örnek bir İlk madde ve malzeme alış kaydı aşağıda yer almaktadır;

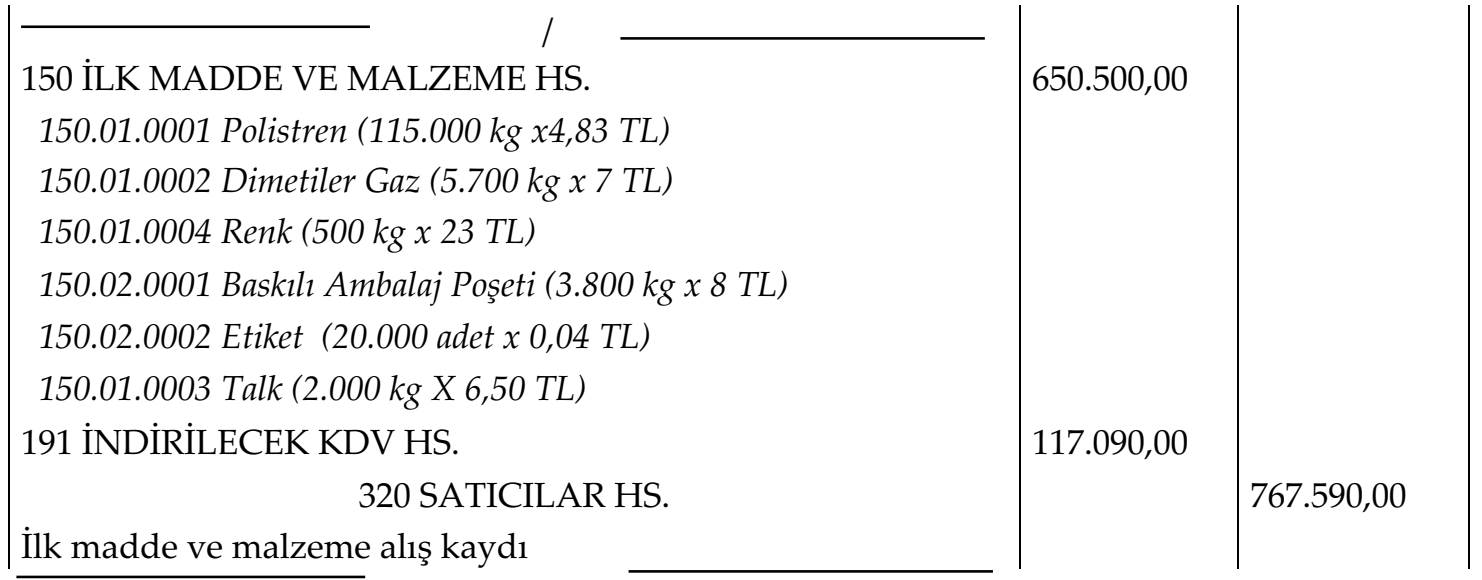

İlgili dönemde Direkt ilk madde ve malzemeler üretime verildiğinde aşağıdaki gibi kayıt yapilacaktır; 


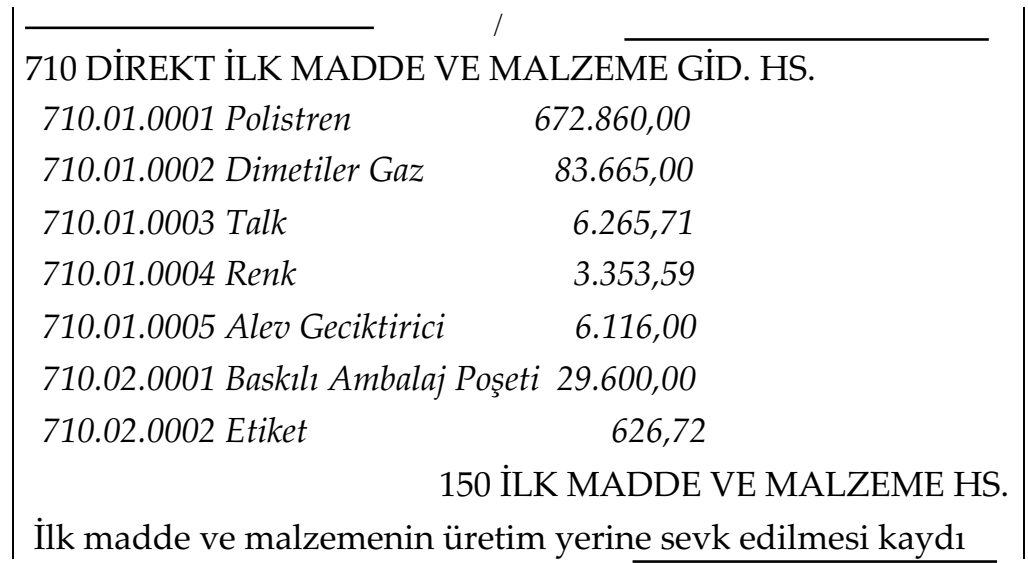

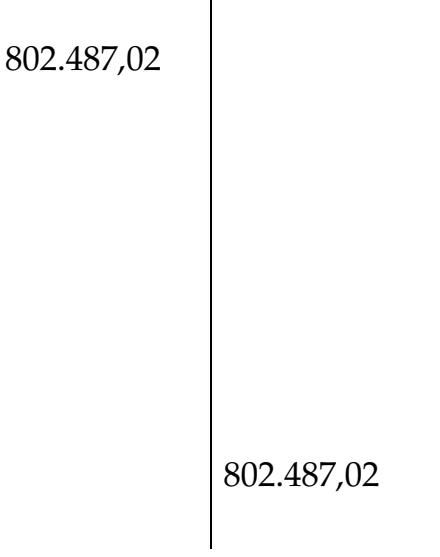

İşçilik giderinin hesaplanmasında asgari ücret tutarı 1.777,50 TL olarak alınmıştır. Üretim yerinde yılın ilk altı ayında 5 işçi, son altı ayında 4 işçi çalışmıştır. İlgili dönemde işçiler 421 saat fazla mesai yapmışlardır. Fazla mesai ücretleri toplamı ise 4.988,85 TL'dir. Fazla mesai ücreti normal saatlik çalışma ücretinin \%50 zamlı şeklinde ödenmektedir. İlgili dönemde normal saatlik çalışma ücreti 7,9 TL (1.777,50 TL/ 225 saat) 'dir. Bunun \%50 zamlı ücreti 11,85 TL (7,9 TL x 1,5=11,85 TL)'dir. Fazla mesai ücretinin 7,9 TL'lik kısmı Fazla mesainin normal saat ücretinde (421 saat $\times 7,9 \mathrm{TL}=3.325,90 \mathrm{TL}$ ), 3,95 TL'lik kısım ise Fazla mesai ücret farkında (421 saat x 3,95 $\mathrm{TL}=1.662,95 \mathrm{TL}$ ) muhasebeleştirilmektedir.

İşletmede, üretim süresince gerçekleşen direkt işçilik gideri brüt ücret ile fazla mesainin normal saat ücreti toplanarak bulunmaktadır. İlgili dönemde Brüt ücret 95.985 TL ( Günlük ücret $(7,9$ TL x 7,5 Saat= 59,25 TL) x Toplam Çalışılan İşgünü $(1.620$ Gün $)=95.985$ TL)'dir. Fazla mesainin normal saat ücreti 3.325,90 TL (Normal saat ücreti $(7,9$ TL) x Fazla mesai saati (421 saat) $=3.325$, 90 TL)' dir. Direkt işçilik gideri 99.310,90 TL (95.985 TL+3.325,90 TL= 99.310,90 TL)'dir.

Genel üretim gideri 24.382,07 TL'dir. SGK işveren katkı payından, İşveren işsizlik priminden ve fazla mesai ücret farkından oluşmaktadır. SGK İşveren Katkı Payı 20.699,64 TL'dir. Bunun hesaplanması için işçinin brüt ücret tutarı ile fazla mesai ücretleri toplanmıştır (95.985 TL + 4.988,85 TL= 100.973,85 TL). Bu tutar üzerinden \%20,5 katkı payı hesaplanmıştır $(100.973,85 \mathrm{TL}$ x \%20,5= 20.699,64 TL). İşveren İşsizlik Primi 2.019,48 TL'dir. Bunun hesaplanması için SGK matrahı olan 100.973,85 TL üzerinden \%2 işsizlik primi hesaplanmıştır $(100.973,85$ TL x \%2= 2.019,48 TL). Fazla mesai ücreti fark1 1.662,95 TL'dir (3,95 TL x 421 Saat=1.662,95 TL).

Ödenecek vergi ve fonların hesaplanmasında gelir vergisi matrahının yani toplam brüt ücretin \%85 'i alınarak (SGK Primi ve İsssizlik kesintisi düşülerek) kümülatif gelir vergisi matrahının 13.000 TL'ye kadar olan kısmı \%15'den, 13.0001 TL 'den 30.000 TL'ye kadar olan kısm \%20 oranından hesaplanmıştır. Bu hesaplamalar sonucunda Gelir vergisi 14.112,29 TL olarak bulunmuştur. Damga vergisi ise toplam brüt ücretin \%0,0759 ' u oranında olup bu da 766,39 TL olarak hesaplanmıştır. Ödenecek vergi ve fonlar 14.878,68 TL $(14.112,29 \mathrm{TL}+766,39 \mathrm{TL}$ $=14.878,68 \mathrm{TL})^{\prime}$ dir.

Ödenecek Sosyal Güvenlik Kesintisi toplamı, SGK primi ile işsizlik priminden oluşmaktadır. SGK primi, Fazla mesai ücret farkı hesabı (1.662,95 TL) ile Direkt İşçilik Gideri (99.310,90 TL) toplamının \% 34,5' i (\%14'ü işçiden kesilen SGK Primi, \%20,5 işveren katkı payı) alınarak hesaplanmaktadır. SGK primi 34.835,98 TL [(1.662,95 TL + 99.310,90 TL) x \% 34,5] 'dir. İşsizlik primi 3.029,22 TL (100.973,85 TL x \%3)'dir. Aynı matrahın \%3' ü (\%2 işveren katkı payı, \%1'i işçiden kesilen SGK primi) alınarak hesaplanmaktadır. Üretim maliyetini etkilemediği için SGK teşvikleri ihmal edilmiştir. Ödenecek Sos. Güv. Kes 37.865,19 TL'dir. 
İşçilerimizin hepsi eşi çalışmayan üç çocukludur. İlgili yıldaki Asgari Geçim İndirimi Tablosuna göre evli, eşinin geliri olmadığı ve üç çocuklu çalışan için Asgari Geçim İndirimi tutarı aylık 226,63 TL'dir. İşletmede yılın ilk altı ayında çalışan 5 işçinin altı aylık Asgari Geçim İndirimi toplamı 6.798,90 TL (226,63 TL x 5 İşçi= 1.133,15 x 6 ay=6.798,90 TL) olarak hesaplanmıştır.

Yılın diğer altı ayında çalışan 4 işçinin altı aylık Asgari Geçim İndirimi toplam 5.439,12 TL $(226,63 \mathrm{TL} \times 4$ işçi=906,52 TL $\times 6$ ay= 5.439,12 TL)'dir.

İlgili dönemde toplam Asgari Geçim İndirimi 12.238,02 TL (6.798,90 TL + 5.439,12 TL= 12.238,02 TL)' dir. Asgari geçim indirimi ilgili işletmede Gelir vergisi tutarından mahsup edilerek (14.112,29 TL -12.238,02 TL) kayda alınmaktadır.

İşletmenin işçilik gider kaydı aşağıdaki gibidir;

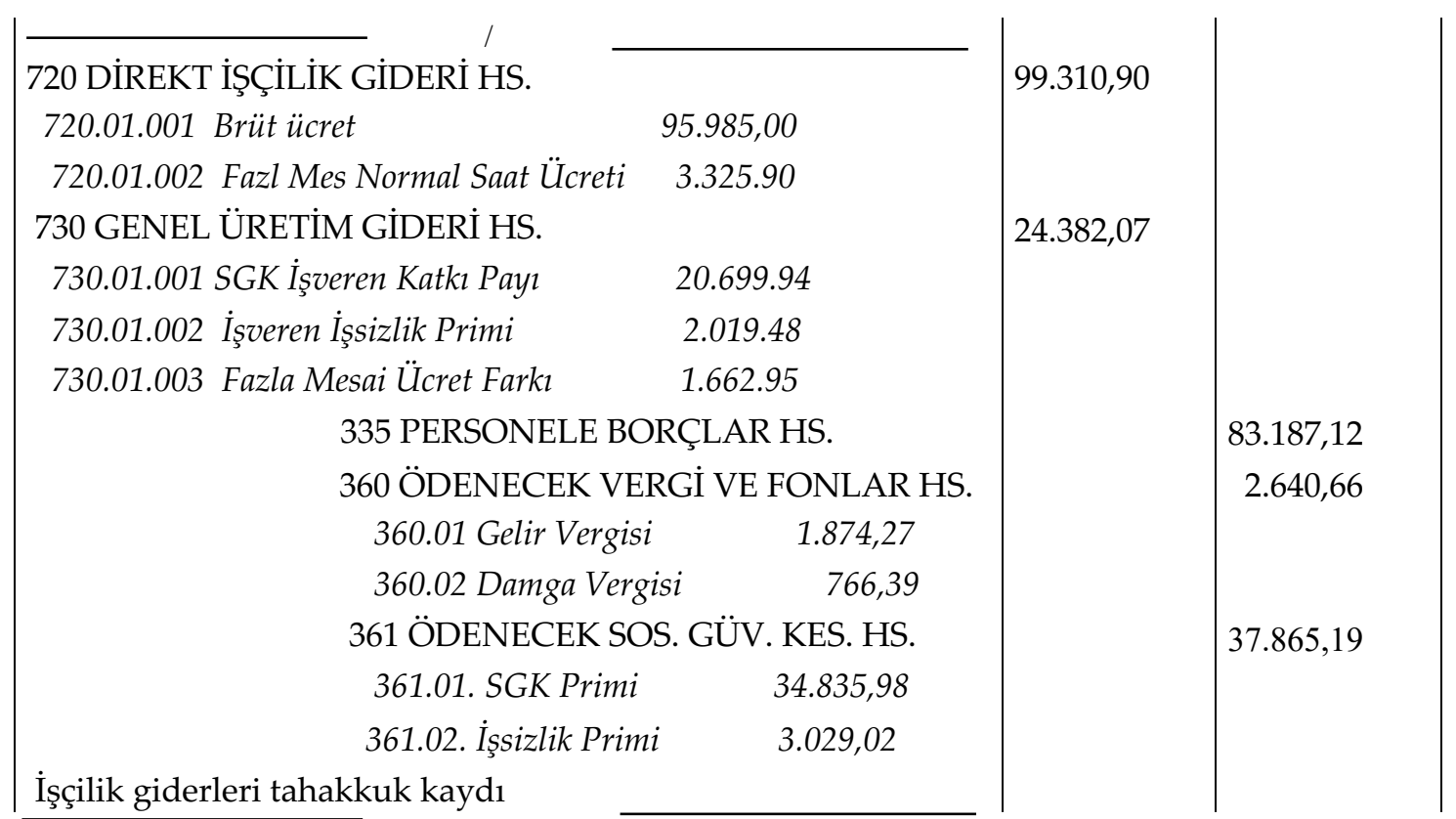

Endirekt giderler; amortisman giderlerinden, kasko giderinden, elektrik giderinden, akaryakıt giderinden ve endirekt işçilik giderinden oluşur. Toplam GÜG 369.282,63 TL'dir.
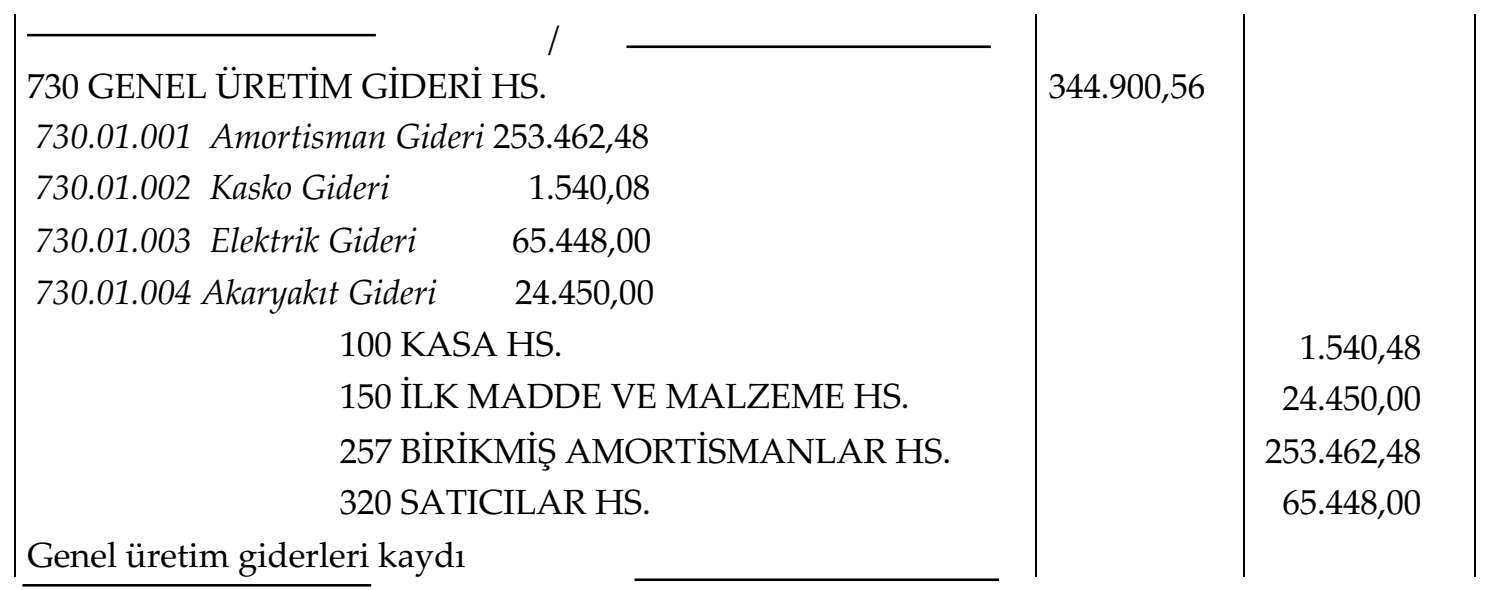
Üretilen mamulün maliyetinin ilgili hesaba yansıtılması kaydı aşağıdaki gibi olacaktır;

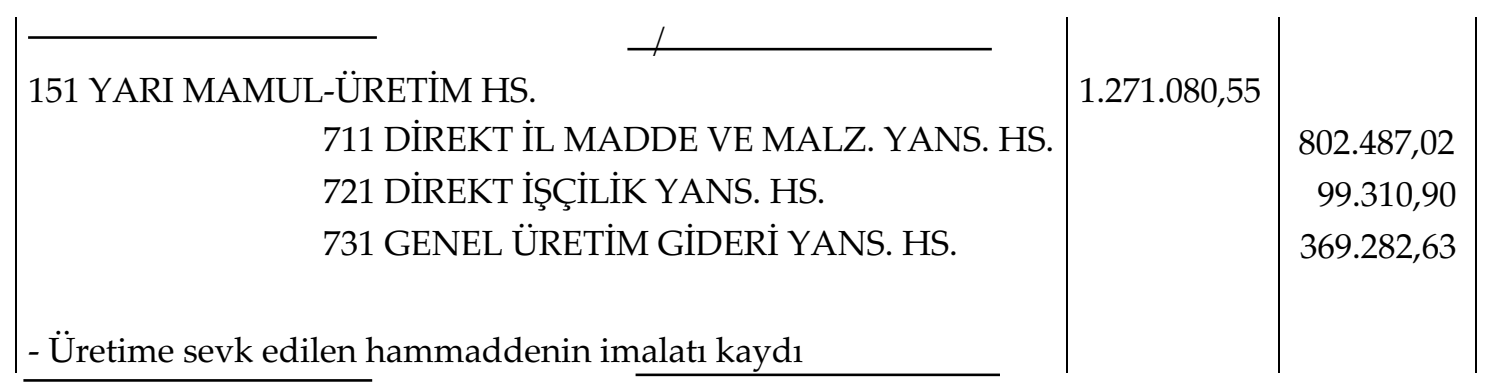

Tamamlanan mamuller mamul stok hesabına aşağıdaki gibi alınacaktır;

$\mid$\begin{tabular}{l|l|}
\hline $\begin{array}{l}152 \text { MAMULLER HS. } \\
151 \text { YARI MAMUL-ÜRETIM HS. }\end{array}$ & $1.267 .337,45$ \\
$\begin{array}{l}\text { - Yarı mamul-üretimlerin tamamlanarak mamul hesabına } \\
\text { devredilmesi kaydı }\end{array}$ & $1.267 .337,45$ \\
\hline
\end{tabular}

Dönemde üretim yerinde 802.487,02 TL tutarında direkt hammadde kullanılmış, 99.310,90 TL tutarında Direkt İşçilik Gideri tahakkuk etmiş ve 369.282,63 TL tutarında endirekt gidere katlanılmıştır. Tamamlanan mamul maliyeti 1.267.337,45 TL olarak gerçekleşmiştir. Bir sonraki başlıkta Toplam üretim maliyeti ile birim üretim maliyeti hesaplanacaktır.

\section{5. Örnek İşletmede Üretilen XPS Isı Yalıtım Levhasının Toplam Üretim Maliyeti ve Birim Üretim Maliyetinin Hesaplanması}

Isı yalıtım sektöründe faaliyet gösteren ve XPS 1Sı yalıtım levhası üreten işletmede, ebat ve yoğunlukları (danste) açısından 6 çeşit ısı yalıtım levhası üretilmektedir. 24-26 danste (bir $\mathrm{m}^{3}{ }^{\prime}$ ün $\mathrm{kg}$ karşılığı) üretim, işletmenin üretmiş olduğu ürün çeşitlerinin hepsinde yer almasından dolayı birim maliyet hesaplamasında 24-26 danste üretim dikkate alınmıştır. Tablo 2.'de üretim maliyeti hesaplanmış olan ürün çeşitleri ve özellikleri gösterilmiştir.

Tablo 2. Üretim Maliyeti Hesaplanan Ürün Çeşitleri ve Özellikleri

\begin{tabular}{|c|c|c|c|c|}
\hline Kalınlık (cm) & Ebad $\mathbf{( c m})$ & $\mathbf{m}^{3}$ & Tip & Yoğunluk $\mathbf{( k g})$ \\
\hline $2 \mathrm{~cm}$ & $600 \times 1200$ & 0,288 & BYP 2000 & $24-26$ Danste \\
\hline $3 \mathrm{~cm}$ & $600 \times 1200$ & 0,3024 & BYP 2000 & $24-26$ Danste \\
\hline $4 \mathrm{~cm}$ & $600 \times 1200$ & 0,288 & BYP 2000 & $24-26$ Danste \\
\hline $5 \mathrm{~cm}$ & $600 \times 1200$ & 0,288 & BYP 2000 & $24-26$ Danste \\
\hline $6 \mathrm{~cm}$ & $600 \times 1200$ & 0,3024 & BYP 2000 & $24-26$ Danste \\
\hline $7 \mathrm{~cm}$ & $600 \times 1200$ & 0,3024 & BYP 2000 & $24-26$ Danste \\
\hline
\end{tabular}

XPS ısı yalıtım levhasının üretiminde 7 çeşit malzeme kullanılmaktadır. Üretimde kullanılan direkt ilk madde ve malzemeler; polistren, talk, renk, alev geciktirici ve dimetiler gaz'dır. Endirekt ilk madde ve malzemeler ise baskılı ambalaj poşeti ve etiket' tir. Bunlar imalata belirli ölçülerde verilmektedir. Tablo 3.'de üretime verilen malzemelerin miktarları ve maliyetleri verilmiştir. Ayrıca tabloda, üretimin gerçekleştirilmesinde malzemelerin hangi oranlarda kullanıldığı da açıklanmıştır. 
Tablo 3. Örnek İşletmede 24-26 Danste XPS Isı Yalıtım Levhasının Üretiminde Kullanılan Malzemenin Miktarı (kg) ve Maliyeti

\begin{tabular}{|c|c|c|c|c|c|c|}
\hline Hesap adı & Açıklama & $\begin{array}{c}\text { Kullanılan } \\
\text { Malzemelerin } \\
\text { Toplam } \\
\text { Maliyeti (TL) }\end{array}$ & $\begin{array}{c}\text { Kullanılan } \\
\text { Kalıcı } \\
\text { Malzeme } \\
\text { Toplamı } \\
\mathbf{( k g}\end{array}$ & $\begin{array}{c}\text { Kullanılan } \\
\text { Malzeme } \\
\text { Maliyeti }\end{array}$ & $\begin{array}{c}\text { Kullanılan } \\
\text { Malzeme } \\
\text { Miktarı } \\
\mathbf{( k g )}\end{array}$ & $\begin{array}{c}\mathbf{n} \\
\text { Katsayı } \\
\mathbf{s 1} \mathbf{\%}\end{array}$ \\
\hline 710 DİMMG & İmal. Ver. Ham. & $802.487,02$ & $152.899,60$ & & & \\
\hline Polistren & İmal. Ver. Ham. & & & $672.860,00$ & $146.396,00$ & 0,9575 \\
\hline Talk & İmal. Ver. Ham. & & $6.265,71$ & $1.032,00$ & 0,0067 \\
\hline Renk & İmal. Ver. Ham. & & & $3.353,59$ & 242,60 & 0,0016 \\
\hline Alev Geciktirici & İmal. Ver. Ham. & & $6.116,00$ & $1.529,00$ & 0,0100 \\
\hline Baskılı Amb. Poş. & İmal. Ver. Ham. & & $29.600,00$ & $3.700,00$ & 0,0242 \\
\hline Etiket & İmal. Ver. Ham. & & & 626,72 & $18.195,00$ & 0,1190 \\
\hline Dimetileter Gaz & İmal. Ver. Ham. & & & & & 1,00 \\
\hline \hline & & & & & & \\
\hline \hline
\end{tabular}

Yukarıdaki Tablo 3'de ilgili dönemde 24-26 danste XPS 1sı yalıtım levhasının üretimi için kullanmış olan malzeme miktarı $(\mathrm{kg})$ ve maliyetleri yer almaktadır. Dönem başı yarı mamul 810 kg'dır. Tabloda görüldüğü üzere ilgili dönemde 152.899,60 kg kalıcı malzemeyle birlikte dönem başından gelen $810 \mathrm{~kg}$ yarı mamul üretime verilmiştir. Üretime verilen 152.899,60 kg kalıcı malzemenin 146.396,00 kg'1 polistrendir. 1.032,00 kg'1 talktır. 242,60 kg'1 renktir. 1.529,00 kg'1 alev geciktiricidir. Endirekt ilk madde ve malzeme olarak $3.700,00 \mathrm{~kg}$ baskılı ambalaj poşeti yer almaktadır. Kullanılan maddelerin kalıcı ağırlıklarının (kg'larının) ve kullanım yüzdelerinin hesaplamasında dimetileter gazın ve etiketin kg'ları ve yüzdeleri ihmal edilmiştir. Bunun nedeni, gazın uçucu olması ve etiketin düşük bir ağırlığa $(\mathrm{kg})$ sahip olmasıdır.

Üretime verilen malzemelerin işletmeye olan toplam maliyeti 802.487,02 TL'dir. Üretime verilen $146.396,00 \mathrm{~kg}$ polistrenin işletmeye olan toplam maliyeti $672.860,00 \mathrm{TL}$ 'dir. Üretime verilen $1.032,00 \mathrm{~kg}$ talkın işletmeye olan maliyeti 6.265,71 TL'dir. Diğer üretime verilen direkt ilk madde ve malzememiz renk' tir. Üretime verilen $242,60 \mathrm{~kg}$ renk' in işletmeye olan maliyeti 3.353,59 TL'dir. Üretime verilen $1.529,00 \mathrm{~kg}$ alev geciktiricinin işletmeye olan maliyeti $6.116,00$ TL'dir. Mamul maddenin ambalajında kullanılan endirekt ilk madde ve malzememiz baskılı ambalaj poşetidir. Kullanılan $3.700,00 \mathrm{~kg}$ baskılı ambalaj poşetinin işletmeye olan maliyeti 29.600,00 TL'dir. Baskılı ambalaj poşetinin üzerine yapıştırılan ve ürünün özelliğini gösteren diğer endirekt ilk madde ve malzememiz etikettir. 18.195,00 adet etiket kullanılmıştır. Bunun işletmeye olan maliyeti 626,72 TL'dir. Üretime verilen 13.040,00 kg dimetileter gazın işletmeye olan toplam maliyeti 83.665,00 TL'dir.

Tabloda yer alan $\mathrm{n}$ katsayısı, $1 \mathrm{~m}^{3}$ içerisinde yer alan kalıcı hammaddelerin yüzdesini göstermektedir. $\mathrm{Bu}$ yüzdeler kullanılan malzeme miktarının, kullanılan kalıcı malzeme toplamına bölünmesi suretiyle hesaplanmaktadır. Üretimin gerçekleştirilmesinde kullanılan malzemelerin \%95,75 $(146.396,00 \mathrm{~kg} / 152.899,60 \mathrm{~kg})^{\prime} \mathrm{i}$ polistrendir. \%0,67 $(1.032,00 \mathrm{~kg} / 152.899,60$ kg)'si talktır. \%0,16 (242,60 kg/152.899,60 kg)'s1 renktir. \% $1(1.529,00 \mathrm{~kg} / 152.899,60 \mathrm{~kg})$ 'i alev geciktiricidir. \%2,42 (3.700,00 kg/152.899,60 kg)'si ise baskılı ambalaj poşetidir.

Üretime verilen malzemelerin bir kısmının üretimi tamamlanmıştır. Üretimi tamamlanan mamuller, stok alanında ait oldukları bölümlere alınmıştır. Dönem sonunda, üretimi henüz tamamlanmamış ve mamul hale dönüşmemiş olan yarı mamul bulunmaktadır. Tablo 4'de mamule dönüşen malzemenin miktarı ve maliyeti yer almaktadır. Mamule dönüşen malzemelerin miktarları $(\mathrm{kg})$ içerisinde, hangi malzemenin hangi oranda bulunduğu da 
açıklanmıştır. Ayrıca tabloda, $1 \mathrm{~m}^{3}$ XPS'in içerisinde kalıcı malzemelerin ağırlığı ve kullanılan malzemelerin $\mathrm{m}^{3}$ maliyeti de hesaplanmıştır.

Tablo 4. Örnek İşletmede Mamule Dönüşen Malzemenin Miktarı (kg) ve Maliyeti

\begin{tabular}{|c|c|c|c|c|c|c|c|}
\hline Hesap adı & $\begin{array}{l}\text { Mamule } \\
\text { Dönüşen } \\
\text { Kalıcı } \\
\text { Malzeme } \\
\text { Toplamı } \\
\text { (kg) }\end{array}$ & $\begin{array}{c}\text { Mamule } \\
\text { Dönüşen } \\
\text { Malzeme } \\
\text { Miktarı } \\
\text { (kg) }\end{array}$ & $\begin{array}{c}\mathbf{n} \\
\text { Katsayisı } \\
\%\end{array}$ & $\begin{array}{c}\text { Mamule } \\
\text { Dönüşen } \\
\text { Malzemenin } \\
\text { Toplam } \\
\text { Maliyeti (TL) }\end{array}$ & $\begin{array}{c}\text { Mamulle } \\
\text { Dönüşen } \\
\text { Malzeme } \\
\text { Maliyeti }\end{array}$ & $\begin{array}{c}\mathrm{m}^{3} / \mathrm{kg}- \\
\text { adet }\end{array}$ & $\mathrm{m}^{3} / \mathrm{TL}$ \\
\hline 710 DİMMG & $152.780,00$ & & & $798.743,92$ & & & \\
\hline Polistren & & $146.281,49$ & 0,7950 & & $\begin{array}{c}634.989,8 \\
5\end{array}$ & 23,07 & 100,13 \\
\hline Talk & & $1.031,19$ & 0,0056 & & $4.476,28$ & 0,16 & 0,71 \\
\hline Renk & & 242,41 & 0,0013 & & $1.052,27$ & 0,04 & 0,17 \\
\hline Alev Geciktirici & & $1.527,80$ & 0,0083 & & $6.632,01$ & 0,24 & 1,05 \\
\hline $\begin{array}{c}\text { Baskıll Amb. } \\
\text { Poş. }\end{array}$ & & $3.697,11$ & 0,0201 & & $16.112,30$ & 0,58 & 2,54 \\
\hline Etiket & & $18.180,77$ & 0,0988 & & $78.920,46$ & 2,87 & 12,45 \\
\hline Dimetileter Gaz & & $13.029,80$ & 0,0708 & & $56.560,75$ & 2,05 & 8,92 \\
\hline & & & 1,00 & & & 24,09 & $\overline{125,96}$ \\
\hline
\end{tabular}

Yukarıdaki Tablo 3'de açıklandığı üzere, ilgili dönemde 152.899,60 kg malzemeyle birlikte dönem başından gelen $810 \mathrm{~kg}$ yarı mamul kullanılmıştır. Bunların 152.780,00 kg'ının mamule dönüştürüldüğü yukarıdaki Tablo 4'de gösterilmiştir. Dönem sonunda kalan 929,60 kg (7.593,10 TL) yarı mamul ise bir sonraki döneme aktarılmıştır.

İşletmede $152.780,00 \mathrm{~kg}$ kalıcı malzeme ile $6.341,40 \mathrm{~m}^{3}$ 24-26 danste XPS 1sı yalıtım levhası üretilmiştir. Mamule dönüşen kalıcı malzemelerin 146.281,49 kg'1 polistrendir. 1.031,19 kg'1 talktır. 242,41 kg'1 renktir. 1.527,80 kg'1 alev geciktiricidir. $3.697,11 \mathrm{~kg}^{\prime} 1$ ise bask1lı ambalaj poşetidir. Mamule dönüşen malzemelerin kalıcı ağırlıklarının ( $\left.\mathrm{kg}^{\prime} l \mathrm{ların} ı n\right)$ hesaplanmasında ve $\mathrm{m}^{3} / \mathrm{kg}$-adet hesaplamalarında dimetileter gaz ve etiket $\mathrm{kg}^{\prime} l a r ı$ ihmal edilmiştir. Bunun nedeni gazın uçucu olması ve etiketin düşük bir ağırlığa sahip olmasıdır.

Tabloda yer alan $\mathrm{n}$ katsayısı, $1 \mathrm{~m}^{3 \prime}$ ü oluşturan bütün malzemelerin tutarının yüzdesini göstermektedir. Bu yüzdeler mamule dönüşen malzeme miktarının, mamule dönüşen malzeme miktarının toplamına bölünmesi suretiyle hesaplanmaktadır. Mamule dönüşen malzemelerin \% $79,50(146.281,49 \mathrm{~kg} / 183.990,57 \mathrm{~kg})^{\prime} \mathrm{i}$ polistrendir. \% 0,56 (1.031,19 kg/183.990,57 kg) 'i talktır. \% 0,13 (242,41 kg/183.990,57 kg)'ü renktir. \% 0,83 (1.527,80 kg/183.990,57 kg)'ü alev geciktiricidir. \%2,01 (3.697,11 kg/183.990,57 kg)'i baskılı ambalaj poşetidir. \% 9,88 (18.180,77 kg/183.990,57 $\mathrm{kg})^{\prime}$ i etikettir. \%7,08 (13.029,80 kg/183.990,57 kg)'i ise dimetileter gazdır.

Mamule dönüşen malzemenin işletmeye olan toplam maliyeti 798.743,92 TL'dir. Üretimde kullanılan 146.281,49 kg'1 polistrenin işletmeye olan toplam maliyeti 634.989,85 TL'dir. $1 \mathrm{~m}^{3}$ XPS' in içerisinde kalıcı malzemelerin ağırlığı ortalama 24,09 kg gelmektedir. 24,09 kg XPS 1S1 yalıtım levhasının içerisinde $23,07 \mathrm{~kg}$ polistren bulunmaktadır. Polistrenin $\mathrm{m}^{3}$ maliyeti ise 100,13 TL'dir.

XPS isı yalıtım levhasının üretiminde 1.031,19 kg talkın işletmeye olan maliyeti 4.476,28 TL'dir. $1 \mathrm{~m}^{3} \mathrm{XPS}^{\prime}$ in içerisinde $0,16 \mathrm{~kg}$ talk bulunmaktadır. Talkın $\mathrm{m}^{3}$ maliyeti ise 0,71 TL'dir. 
XPS 1Sı yalıtım levhasının üretiminde kullanılan diğer malzeme renktir. Toplam üretimin içerisinde $242,41 \mathrm{~kg}$ kullanılan rengin işletmeye olan maliyeti 1.052,27 TL'dir. $1 \mathrm{~m}^{3} \mathrm{XPS}^{\prime}$ in içerisinde $0,04 \mathrm{~kg}$ renk bulunmaktadır. Rengin $\mathrm{m}^{3}$ maliyeti ise $0,17 \mathrm{TL}^{\prime}$ dir.

Üretimin gerçekleştirilmesinde 1.527,80 kg alev geciktirici kullanılmıştır. Bunun işletmeye olan maliyeti 6.632,01 TL'dir. $1 \mathrm{~m}^{3} \mathrm{XPS}^{\prime}$ in içerisinde $0,24 \mathrm{~kg}$ alev geciktirici bulunmaktadır. Alev geciktiricinin $\mathrm{m}^{3}$ maliyeti 1,05 TL'dir.

Mamul maddenin ambalajında kullanılan diğer endirekt ilk madde ve malzeme baskılı ambalaj poşetidir. Toplam üretimin içerisinde $3.697,11 \mathrm{~kg}$ baskılı ambalaj poşeti kullanılmıştır. Bunun işletmeye olan maliyeti 16.112,30 TL'dir. $1 \mathrm{~m}^{3}$ XPS' in içerisinde 0,58 kg baskılı ambalaj poşeti kullanılmıştır. Baskılı ambalaj poşetinin $\mathrm{m}^{3}$ maliyeti 2,54 TL'dir.

Baskılı ambalaj poşetinin üzerine yapıştırılan ve ürünün özelliğini gösteren diğer endirekt ilk madde ve malzeme etikettir. Toplam üretimin içerisinde 18.180,77 adet kullanılmıştır. Bunun işletmeye olan maliyeti 78.920,46 TL'dir. Etiketin $\mathrm{m}^{3}$ maliyeti ise 12,45 TL'dir.

Dimetileter gaz toplam üretimin içerisinde $13.029,80 \mathrm{~kg}$ kullanılmıştır. Bunun işletmeye olan toplam maliyeti 56.560,75 TL'dir. Dimetiler gazın $\mathrm{m}^{3}$ maliyeti 8,92 TL'dir.

İlgili dönemde $6.341,40 \mathrm{~m}^{3}$ XPS ısı yalıtım levhası üretilmiştir. Üretilen bu levhaların $5.775 \mathrm{~m}^{3}$ (1.148.747,12 TL)'ü dönem içerisinde satılmıştır. Tablo 5'de 6.341,40 $\mathrm{m}^{3}$ XPS $1 \mathrm{~s}$ yalıtım levhası üretiminin gerçekleştirilebilmesi için katlanılan toplam üretim gideri gösterilmiştir. Tabloda yer alan bilgilerden hareketle birim üretim maliyeti hesaplanmıştır.

Tablo 5. Örnek İşletmenin İlgili Dönemdeki Toplam Üretim Giderinin, Toplam Üretim $\left(\mathrm{m}^{3}\right)$ Miktarının ve Satılan XPS $\left(\mathrm{m}^{3}\right)$ Miktarının Tespit Edilerek Birim Üretim Maliyetinin Hesaplanmasi

\begin{tabular}{|c|c|c|}
\hline \multicolumn{3}{|c|}{ 6.341,40 $\mathrm{m}^{3}$ Üretim İçin Katlanılan Gider } \\
\hline & Toplam & $\mathrm{m}^{3} / \mathrm{TL}$ \\
\hline (710) Direkt İlk Mad. Ve Malz. Gid. & $798.743,92$ & 125,96 \\
\hline (720) Direkt İşçilik Gideri & $99.310,90$ & 15,66 \\
\hline (730) Genel Üretim Gideri & $369.282,63$ & 58,23 \\
\hline - Endirekt İşçilik & $24.382,07$ & \\
\hline - Elektrik & $65.448,00$ & \\
\hline -Akaryakit & $24.450,00$ & \\
\hline -Amortisman & $253.462,48$ & \\
\hline - Diğer Giderler (Kasko) & $1.540,08$ & \\
\hline TOPLAM ÜRETİM GİDERİ & $1.267 .337,45$ & 199,85 \\
\hline
\end{tabular}

Yukarıdaki Tablo 5'de ilgili dönemde 6.341,40 $\mathrm{m}^{3}$ 24-26 danste XPS 1S1 yalıtım levhasının üretildiği bilgisi yer almaktadır. $6.341,40 \mathrm{~m}^{3} \mathrm{XPS}$ 1sı yalıtım levhasının üretimi için 798.743,92 TL direkt ilk madde ve malzeme giderine, 99.310,90 TL direkt işçilik giderine ve 369.282,63 TL genel üretim giderine katlanılmıştır. 369.282,63 TL genel üretim gideri içerisinde 24.382,07 TL endirekt işçilik gideri, üretimin gerçekleştirilebilmesi için 65.448,00 TL elektrik gideri, fabrika içerisinde hammadde sevkiyatının yapılması ve üretilen mamullerin stok alanına alınması amacıyla kullanılan forklift için 24.450,00 TL akaryakıt gideri, kullanılan makine ve tesisleri için 253.462,48 TL amortisman gideri ve 1.540,08 TL kasko gideri yer almaktadır.

İşletmede birim üretim maliyeti, toplam üretim maliyetinin toplam üretim miktarına bölünmesi suretiyle hesaplanmaktadır. İlgili dönemdeki toplam üretim maliyeti 1.267.337,45 TL'dir. Toplam üretim miktarı ise yukarıda belirtildiği gibi $6.341,40 \mathrm{~m}^{3}$ tür. Bu verilerden hareketle birim üretim maliyeti 199,85 TL/ $\mathrm{m}^{3}\left(1.267 .337,45 \mathrm{TL} / 6.341,40 \mathrm{~m}^{3}\right)$ bulunmuştur. 


\section{SONUÇ ve ÖNERİLER}

Çağın gereği olarak teknoloji alanında hızlı bir değişim yaşanmaktadır. Yaşanan bu hızlı değişim, enerjiye olan ihtiyacı ve tüketimi arttırmaktadır. Bu durum enerji bakımından dışarıya bağımlı olan ülkemiz açısından bir takım tedbirlerin alınmasını gerekli kılmıştır. Enerjinin, sanayide verimli kullanımının sağlanmasının yanı sıra yapılarda kullanılan enerji miktarında da tasarrufun sağlanması gerekmektedir. Kullanılan enerji miktarında tasarrufun sağlanabilmesinde, 1sı yalıtım uygulamalarının önemi küçümsenemeyecek boyuttadır.

Çalışmanın uygulama kısmı Kahramanmaraş ilinde faaliyette bulunan bir XPS 1sı yalıtım işletmesinde gerçekleştirilmiştir. Uygulamanın gerçekleştirildiği işletmede, XPS 1sı yalıtım levhalarının üretim süreci gözlemlenmiş ayrıca ilgili kişilerden üretimin nasıl gerçekleştirildiği konusunda bilgiler alınmış olunup üretim şeması hazırlanmıştır. Bununla birlikte muhasebe departmanındaki yetkili kişiler ile görüşülmüş ve mevcut maliyet sistemi incelenmiştir. Ayrıca gerek stok takip yöntemleri gerek düzenlenmesi gereken belgeler, gerekse muhasebeleştirme konularında önerilerde bulunulmuştur.

İşletmede stok kontrol yöntemi olarak gözle kontrol yöntemi kullanılmaktadır. Gözle kontrol yöntemi, verilen sipariş düzeylerinin ve miktarlarının kişisel yargıya dayalı olması sebebiyle hatalara neden olmaktadır. Bu hatanın ortadan kaldırılması için stok kontrol yöntemi olarak çift kutu yönteminin uygulanması önerilmektedir.

İlgili işletmede malzeme siparişlerinin verilmesinde, malzeme fiyatları ve ihtiyaç durumu göz önünde bulundurulmaktadır. Ayrıca üretimde bir aksama yaşanmaması için en az 2 aylık stok bulundurulmaktadır. Malzeme siparişlerinde, hangi malzemeden ne miktarda siparişin verileceğine, stok alanının gözle sayımı sonucunda karar verilmektedir.. Ancak sayımda yapılan bir hata malzeme sipariş miktarının fazla veya eksik miktarda verilmesine neden olabilmektedir. Malzeme sipariş miktarının yanlış verilmesi konusundaki eksikliğin giderilebilmesi için öncelikli olarak işletmeye gelen her malzemenin düzenli olarak belgelerle takibinin sağlanması gerekir. Bunun için ambar ilk madde ve malzeme stok kartı formu oluşturulmalıdır. Malzeme siparişi verileceği zaman, stok alanının sayımı ile bu form karşılaştırılmalı ve siparişler elde edilen doğru veriler üzerinden verilmelidir.

İşletmede düzenlenmesini önerdiğimiz diğer bilgi ve belgeler; ilk madde ve malzeme satın alma istek fişi, sipariş formu, satın alma formu, teslim alma formu, iade formu, ambara giriş formu, ilk madde ve malzeme üretim giriş formu gibi belgelerdir.

Ayrıca üretilen XPS ısı yalıtım levhaları paketlendikten sonra işletme stok alanındaki paletlerin üzerine taşınmaktadır. Etiketin üzerinde barkod numaralarının olmasına rağmen işletmede barkod takip sistemi uygulanmamaktadır. Barkod takip sisteminin olmamasından dolayı stok alanındaki isı yalıtım levha paketlerinin sayımında hatalar olabilmektedir. Bu hatanın ortadan kaldırılması için işletmede barkod takip sistemine geçilmesi önerilmektedir.

Örnek işletmede elektrik giderinin muhasebeleştirilmesinde "320 Satıcılar hesabı" alacaklı çalıştırılmıştır. Oysa "320 Satıcılar Hesabı" satıcılardan kredili/vadeli olarak alınan mal ve hizmetler için kullanılan bir hesaptır. Elektrik giderinin muhasebeleştirilmesinde "381 Gider Tahakkukları hesabı" ya da "336 Diğer Çeşitli Borçlar hesabına" alacak kaydedilmelidir.

İşletmenin muhasebe kayıtlarında diğer endirekt ilk madde ve malzeme olan baskılı ambalaj poşeti ve etiket "710 Direkt ilk madde ve malzeme hesabında" muhasebeleştirilmiştir. Ancak baskılı ambalaj poşeti ve etiketinin "730 Genel üretim giderleri hesabında" muhasebeleştirilmesi gerekmektedir. 
Üretim yerinde kullanılan elektrik miktarının tespit edilmesi için üretim yeri ve yönetim binası sayaçları ayrı ayrıdır. Bu durum birim maliyetlerin doğru bir şekilde tespit edilmesi açısından önemlidir.

Bu çalışmada, XPS ısı yalıtım levhası üreten bir işletmede uygulama yapılarak XPS ısı yalıtım levhalarının hangi üretim süreçlerinden geçtiği, toplam ve birim üretim maliyetlerinin nasıl hesaplandığı açıklanarak bu konuda literatüre katkı sağlanmaya çalışılmıştır.

\section{KAYNAKÇA}

Alyanak Kaya, F. (2010). Binalarda Isı Yalıtım Kurallarına Uygun Üretiminde Duvar Malzemesi Seçimine Yönelik Öneriler. Süleyman Demirel Üniversitesi Fen Bilimleri Enstitüsü Yayınlanmamış Yüksek Lisans Tezi, Isparta.

Bektaş, V., Çerçevik, A. E. ve Yerel Kandemir, S. (2017). Binalarda Isı Yalıtımının Önemi ve Isı Yalıtım Malzemesi Kalınlığının Yalıtıma Etkisi. Bilecek Şeyh Edebali Üniversitesi Fen Bilimleri Dergisi, 4 (1), 36-42.

Binalarda Isı Yalıtımı Yönetmeliği, 08.05.2000 Tarihli ve 24043 sayılı Resmi Gazete.

Binalarda Isı Yalıtımı Yönetmeliği, 09.10.2008 Tarihli ve 27019 sayılı Resmi Gazete.

Binalarda Enerji Performansı Yönetmeliği, 05.12.2008 Tarihli ve 27075 sayılı Resmi Gazete.

Erkan, Ü. (2017). Isı Yalıtımı ve Enerji Tasarrufu Sağlamaya Yönelik Harcamaların Gider Yazılabilme Durumu?, Mali Çözüm, 27 (Ocak-Şubat), 181-186.

http://docplayer.biz.tr/6926564-Kati-yalitim-malzemeleri-ekstrude-polistren-\%20levha.html (Erişim Tarihi: 14.07.2018).

https://www.guncelgroup.com.tr/makaleler/artik-isi-yalitimi-ve-enerji-tasarrufu-saglamayayonelik-harcamalar-dogrudan-gider-yazilabilecek/ (Erişim Tarihi: 17. 03. 2017).

https://www.mmo.org.tr/sites/default/files/ca3e9b122f61f8f_ek.pdf (Erişim Tarihi: 17. 03. 2019).

http://www.muhasebetr.com/yazarlarimiz/cemdizdar/002/ (Erişim Tarihi: 08.09.2019).

http://www.xpsturkiye.org/sayfa.asp?ID=129 (Erişim Tarihi: 17. 01. 2017).

http://www.yalitimrehberi.net/etiket/xps-nedir (Erişim Tarihi: 17. 01. 2017).

İşbilir, D. (2009). Binalarda Isı Yalıtımı Uygulamaları ve Sorunlarının Araştırılması. Selçuk Üniversitesi Fen Bilimleri Enstitüsü Yayınlanmamış Yüksek Lisans Tezi, Konya.

Karadayı, T. T. ve Yüksek, İ. (2016). Yapılarda Isı Yalıtım Malzemeleri Seçimi Üzerine Bir Araştırma, Tesisat Dergisi, 242 (Şubat), 90-102.

Karayiğit, S. (2015). Enerji Yönetmeliğine Göre Konutların Farklı Isı Yalıtım Malzemeleri İle Yalıtılmasının Ekonomik Analizi Üzerine Bir Araştırma. Kahramanmaraş Sütçü İmam Üniversitesi Fen Bilimleri Enstitüsü Yayınlanmamış Yüksek Lisans Tezi, Kahramanmaraş.

Kaya, T. (2016). Yapılarda Kullanılan Yalıtım Malzemelerinin Enerji Verimliliği Açısından İncelenmesi. Şeyh Edebali Üniversitesi Fen Bilimleri Enstitüsü Yayınlanmamış Yüksek Lisans Tezi, Bilecik. 
Ögetürk, İ. (2019). Binalarda Isı Yalıtım Malzemelerinin Enerji Verimliliği Üzerine Etkisinin Araştırılması. Batman Üniversitesi Fen Bilimleri Enstitüsü Yayınlanmamış Yüksek Lisans Tezi, Batman.

www.baypratik.com/pdf/isi-izolasyonu.pdf (Erişim Tarihi: 17. 01. 2017).

6728 Sayılı Yatırım Ortamının İyileştirilmesi Amacıyla Bazı Kanunlarda Değişiklik Yapılmasına Dair Kanun.

6745 Sayılı Yatırımların Proje Bazında Desteklenmesi İle Bazı Kanun Ve Kanun Hükmünde Kararnamelerde Değişiklik Yapılmasına Dair Kanun. 